\title{
Perencanaan Kebutuhan Bahan Baku Produk LM-Hamburger Bun Jempol dengan Metode Material Requirement Planning
}

\section{Planning the Raw Material of LM-Hamburger Bun Jempol Product Raw Material Requirements using Material Requirement Planning}

\author{
Yevita Nursyanti ${ }^{*}$, Rizky Ramadhan ${ }^{1}$ \\ ${ }^{1}$ Program Studi Manajemen Logistik Industri Elektronika, Politeknik APP, Jl. Timbul No.34, Jagakarsa, Jakarta \\ Selatan 12630, Indonesia
}

Diterima: 14 Februari, 2019 / Disetujui: 3 Juli, 2019

\begin{abstract}
This research aims to determine the planning of raw material requirements for LM-Hamburger Bun Jempol product at PT. Lotte Shopping Indonesia. This research uses Material Requirement Planning (MRP) method with Silver-Meal, Least Total Cost (LTC), and Least Unit Cost (LUC) techniques to calculate the optimal lot size, reorder point time and calculate the smallest total order costs and holding costs. The observation period was carried out for three months, starting from February to April 2018. The data used in this research were product demand data from February to April 2018, and raw material inventory data at the end of April 2018. Comparison of the three techniques it is based on the smallest total inventory costs. The results of these comparisons have been found which have the lowest total cost of the LTC technique of Rp. 17,220,819 while the total cost with Silver-Meal technique is Rp. 17,289,584, and with the LUC technique amounting to Rp. 18,386,458. Therefore, the LTC technique is more economical than the LUC and Silver-Meal techniques because it has the smallest total cost.
\end{abstract}

Keywords: Inventory, Material Requirement Planning

\begin{abstract}
ABSTRAK
Penelitian ini bertujuan untuk mengetahui perencanaan kebutuhan bahan baku produk LM-Hamburger Bun Jempol pada PT. Lotte Shopping Indonesia. Penelitian ini menggunakan metode Material Requirement Planning (MRP) dengan Teknik Silver-Meal, Least Total Cost (LTC), dan Least Unit Cost (LUC) untuk menghitung ukuran lot optimal, waktu pemesanan ulang (reoder point), dan menghitung total biaya pesan dan biaya simpan terkecil. Periode pengamatan dilakukan selama tiga bulan, dimulai sejak Februari s/d April 2018. Data yang digunakan dalam penelitian ini yaitu data permintaan produk pada bulan Februari s/d April 2018, dan data persediaan bahan baku akhir bulan April 2018. Perbandingan dari ketiga teknik tersebut didasarkan pada total biaya inventori terkecil. Adapun hasil dari perbandingan tersebut telah didapati yang mempunyai total biaya terendah yaitu teknik LTC sebesar Rp. 17.220.819 sedangkan total biaya dengan teknik Silver-Meal sebesar Rp. 17.289.584, dan dengan teknik LUC sebesar Rp. 18.386.458. Oleh karena itu, teknik LTC lebih ekonomis dibanding dengan teknik LUC dan Silver-Meal karena memiliki total biaya terkecil.
\end{abstract}

Kata Kunci: Persediaan, Perencanaan Kebutuhan Material

\section{PENDAHULUAN}

PT. Lotte Shopping Indonesia merupakan perusahaan yang bergerak pada bidang perkulakan atau grosir (wholesale). PT. Lotte Shopping atau yang disebut Lotte Grosir menjual berbagai macam produk. Produk yang dijual di Lotte Grosir yaitu perlengkapan rumah tangga, buah, sayur, daging, ikan, makanan dalam kemasan, dan produk-produk elektronik.

PT. Lotte Shopping Indonesia memiliki beberapa cabang yang tersebar di seluruh Indonesia. Penelitian dilakukan di cabang Jatake atau disebut Lotte Grosir Jatake. Lotte Grosir

*email: yevita.nursyanti@gmail.com 
Jatake merupakan Kitchen Center PT. Lotte Shopping Indonesia di kawasan Jabodetabek.

Terdapat tiga divisi yang menangani produk yang dijual di Lotte Grosir Jatake yaitu divisi Fresh Food, Dry Food, dan General Merchandising (GMS). Dari ketiga divisi, penelitian dilakukan di divisi Fresh Food. Divisi Fresh Food terbagi ke dalam tiga sub divisi yaitu sub divisi Bakery, Fresh Food, dan Meat and Fish. Dari ketiga sub divisi Fresh Food, kegiatan penelitian dilakukan pada sub divisi Bakery.

Dari ketiga sub divisi Fresh Food, sub divisi Bakery merupakan sub divisi yang paling penting karena sub divisi Bakery merupakan sub divisi yang menyumbang profit tertinggi diantara produk Fresh Food lainnya. Selain sebagai sub divisi yang memiliki profit tertinggi, sub divisi Bakery merupakan pemasok produk Bakery untuk tujuh cabang Lotte Grosir di daerah Jabodetabek. Peran sub divisi Bakery sebagai pemasok membuat sub divisi tersebut menjadi salah satu divisi yang paling penting di Lotte Grosir Jatake. Kegiatan pasokan produk Bakery dilakukan setiap harinya sehingga sub divisi Bakery harus bisa menjaga pasokan produk agar dapat memenuhi permintaan produk Bakery dari Lotte Grosir Cabang Jabodetabek. Secara umum, kegiatan produksi/operasi merupakan suatu kegiatan yang berhubungan dengan penciptaan/pembuatan barang, jasa, atau kombinasinya, melalui proses transformasi dari masukan sumber daya produksi dan operasi keluaran yang diinginkan (Herjanto, 2001).

Persediaan adalah sejumlah bahan-bahan, bagian-bagian yang disediakan dan bahan-bahan dalam proses untuk proses produksi, serta barang-barang jadi/produk yang disediakan untuk memenuhi permintaan dari konsumen atau pelanggan setiap waktu (Rangkuti, 2007).

Permasalahan yang muncul pada sub divisi Bakery yaitu tentang perencanaan kebutuhan bahan baku. Pada saat dilakukan penelitian, ditemukan tidak dilakukan perhitungan dalam perencanaan kebutuhan bahan baku. Untuk mendukung perencanaan persediaan yang baik, dapat digunakan Material Requirement Planning (MRP) (Tersine, 1994). MRP merupakan salah satu metode yang digunakan untuk melakukan perencanaan kebutuhan material yang berdasarkan pada kebutuhan barang jadi. Input utama dari MRP adalah lot size atau ukuran pemesanan yang optimal. Penelitian tentang MRP perencanaan ulang di bagian persediaan bahan baku dengan membandingkan 3 metode lot size yaitu Least Unit Cost, Silver Meal dan Wagner Within Algorithm (Madinah, Sumantri dan Azlia, 2015).

Dengan melakukan perencanaan kebutuhan persediaan bahan baku diharapkan dapat dihasilkan solusi terbaik dalam melakukan perencanaan kebutuhan bahan baku. Oleh karena itu, penelitian ini membahas perencanaan kebutuhan persediaan bahan baku produk LMHamburger Bun Jempol dengan metode MRP. Adapun tujuan dari perencanan material adalah untuk meramalkan permintaan produk yang dinyatakan dalam jumlah produk sebagai fungsi dari waktu serta menetapkan jumlah saat pemesanan bahan baku serta komponen secara ekonomis dan terpadu (Kusuma, 2009).

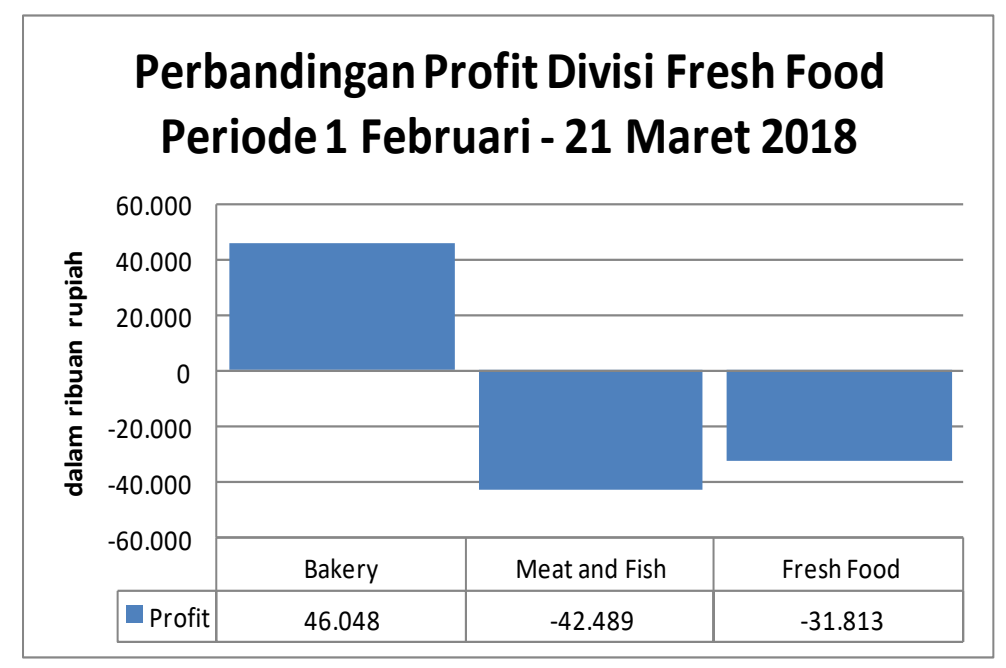

Gambar 1. Perbandingan Profit Divisi Fresh Food 


\section{METODOLOGI}

Gambar 2 menjelaskan metodologi penelitian dilakukan dengan melakukan beberapa tahap yaitu:

1. Identifikasi masalah

Identifikasi masalah dilakukan untuk mengamati permasalah yang terjadi selama dilakukan penelitian.

2. Studi pustaka

Kegiatan studi pustaka dilakukan dengan cara mempelajari teori (study literature) yang berhubungan dengan Material Requirement Planning (MRP).

3. Studi lapangan

Kegiatan studi lapangan dilakukan dengan melihat kondisi aktual yang terjadi pada perusahaan dan membandingkan dengan teori MRP.

4. Pengumpulan data

Pengumpulan data dilakukan dengan beberapa metode yaitu:

a. Observasi

Kegiatan observasi meliputi melakukan pencatatan secara sistematik kejadiankejadian, perilaku, objek-objek yang dilihat dan ha-hal lain yang diperlukan. Data yang didapat dari kegiatan observasi adalah data primer berupa struktur produk LM-Hamburger Bun Jempol.

b. Komunikasi

Teknik komunikasi merupakan teknik yang dilakukan dengan cara melakukan wawancara dengan Leader (Senior Staff) sub divisi Bakery.

c. Dokumentasi

Dokumentasi merupakan sarana pembantu dalam mengumpulkan data atau informasi dengan cara membaca pernyataan tertulis kebijakan tertentu dan bahan-bahan tulisan lainnya. Dalam hal ini, kajian dokumen dilakukan dengan cara mengumpulkan data tertulis yang diperlukan seperti data permintaan produk, data biaya inventori, dan data tertulis lainnya. Dengan menggunakan teknik kajian dokumen, data yang didapat adalah data sekunder yaitu:

1) Data penjualan LM-Hamburger Bun Jempol bulan Februari-April 2018.

2) Data status inventori bahan baku produk LM-Hamburger Bun Jempol.

3) Data lead time bahan baku produk LM-Hamburger Bun Jempol.
4) Data lot size untuk setiap bahan baku produk LM-Hamburger Bun Jempol.

5) Komponen biaya pesan dan biaya simpan.

6) Komposisi bahan baku produk LMHamburger Bun Jempol.

5. Pengolahan data

Pengolahan data dilakukan dengan beberapa cara, yaitu:

a. Melakukan pembuatan Bill of Material (BOM) produk LM-Hamburger Bun Jempol dari data kebutuhan bahan baku pembentuk produk LM-Hamburger Bun Jempol yang telah didapatkan dari bagian Bakery.

b. Melakukan peramalan (forecasting) terhadap permintaan produk LMHamburger Bun Jempol pada bulan Februari-April 2018 untuk dijadikan Jadwal Induk Produksi (JIP) pada bulan Mei-Juli 2018. Terdapat beberapa langkah yang harus diperhatikan untuk menjamin efektivitas dan efisiensi dari sistem peramalan dalam manajemen permintaan seperti memilih item independent demand yang akan diramalkan, menentukan horizon waktu dari peramalan, memilih model-model peramalan (Gaspersz, 2012).

c. Melakukan perhitungan Material Requirement Planning (MRP) dengan menggunakan teknik (Bahagia, 2006):

1) Teknik Least Total Cost (LTC)

Teknik LTC merupakan teknik untuk menentukan ukuran lot pemesanan optimal ketika ongkos simpan dan ongkos pesan berimbang.

2) Teknik Least Unit Cost

Teknik LUC adalah teknik yang menggunakan sifat konvensitas ongkos satuan per-unit (ongkos pesan dan ongkos simpan) terhadap ukuran lot pemesanan.

3) Teknik Silver-Meal

Silver Meal merupakan teknik yang menggunakan satuan ongkos inventori per periode yang terkecil sebagai ukuran kriteria kinerjanya.

4) Lot for lot.

Teknik ini merupakan teknik lot sizing yang paling sederhana dan mudah dimengerti. Pemesanan dilakukan dengan pertimbangan minimasi ongkos simpan. Pada teknik ini, 
pemenuhan kebutuhan bersih dilaksanakan di setiap periode yang membutuhkannya (Ginting, 2007).

Model MRP pada sistem inventori digunakan untuk menentukan kuantitas pesanan persediaan yang meminimalkan biaya langsung penyimpanan persediaan dan biaya pemesanan persediaan (Russell R. S. dan Taylor B. W., 2011).

6. Analisis Perbaikan

Dari hasil perhitungan yang telah dilakukan maka dapat dilakukan analisis perbaikan terhadap permasalahan yang terjadi pada perusahaan. Analisis perbaikan yang dapat diberikan dari hasil penelitian kepada pihak perusahaan adalah:

a. Analisis untuk ukuran lot size yang optimum.

b. Analisis untuk Re-Order Point

c. Analisis total cost.

7. Kesimpulan dan Saran

Dari hasil pengolahan data, akan diambil kesimpulan mengenai ukuran lot pemesanan bahan baku produk LM-Hamburger Bun Jempol. Untuk mengetahui ukuran lot optimal untuk melakukan pemesanan, untuk mengetahui total biaya minimum dari beberapa metode yang digunakan, dan untuk mengetahui kapan saat yang tepat untuk melakukan pemesanan kembali (reorder).

\begin{tabular}{l} 
Pengumpulan Data \\
1. Observasi \\
a. Struktur Produk \\
2. Komunikasi \\
b. Wawancara \\
3. Dokumentasi \\
a. Data Penjualan Produk \\
b. Data Status Inventori Bahan Baku \\
c. Data Lead Time Bahan Baku \\
d. Data Lot Size Bahan Baku \\
e. Komponen Biaya Pesan dan Biaya Simpan \\
f. Komposisi Bahan Baku \\
Pengolahan Data \\
1. Bill of Material (BOM) \\
2. Peramalan untuk membuat Jadwal Induk \\
Produksi (JIP) \\
3. Perhitungan MRP menggunakan Teknik LTC, \\
LUC dan Silver-Meal \\
Analisis Perbaikan \\
1. Analisis Ukuran Lot Optimal \\
2. Analisis Reorder Point \\
3. Analisis Total Cost Minimum \\
\hline
\end{tabular}

Gambar 2. Metodologi Penelitian

\section{HASIL DAN PEMBAHASAN}

\subsection{Bill of Material}

Bill of Material (BOM) menggambarkan struktur produk yang menggambarkan komponen penyusun produk (Fachrurrozi dan Almahdy, 2016). Tabel 1 merupakan daftar bahan baku produk LM-Hamburger Bun Jempol.

Tabel 1. Daftar Bahan Baku Produk

\begin{tabular}{ccc}
\hline No & Bahan Baku & Ukuran $(\mathbf{k g})$ \\
\hline $\mathbf{1}$ & A & 0,25000 \\
$\mathbf{2}$ & B & 0,02500 \\
$\mathbf{3}$ & C & 0,00325 \\
$\mathbf{4}$ & D & 0,00300 \\
$\mathbf{5}$ & E & 0,00125 \\
$\mathbf{6}$ & F & 0,01250 \\
$\mathbf{7}$ & G & 0,02500 \\
$\mathbf{8}$ & H & 0,10000 \\
\hline
\end{tabular}

Berdasarkan daftar kebutuhan bahan baku, maka Bill of Material (BOM) produk LMHamburger Bun Jempol sebagai berikut:

Level 0: Level 1:

Hamburger Bun Jempol

$$
\begin{aligned}
& \text { A }(0,25 \mathrm{~kg}) \mathrm{LT}=1 \text { minggu } \\
& \text { B }(0,25 \mathrm{gr}) \\
& \text { C }(0,00325 \mathrm{~kg}) \mathrm{LT}=1 \text { minggu } \\
& \text { D }(0,003 \mathrm{~kg}) \mathrm{LT}=1 \text { minggu } \\
& \text { E }(0,00125 \mathrm{~kg}) \\
& \mathrm{F}(0,0125 \mathrm{~kg}) \\
& \mathrm{G}(0,025 \mathrm{~kg}) \mathrm{LT}=1 \text { minggu } \\
& \mathrm{H}(0,1 \mathrm{~kg})
\end{aligned}
$$

\subsection{Peramalan Permintaan}

Peramalan digunakan sebagai perkiraan permintaan produk LM-Hamburger Bun Jempol untuk bulan Mei-Juli 2018 dengan data permintaan dari bulan Februari-April 2018. Permintaan produk pada bulan Februari-April 2018 ditunjukkan dalam Tabel 2.

Tabel 2. Data Permintaan

\begin{tabular}{clc}
\hline Periode & \multicolumn{1}{c}{ Tanggal } & $\begin{array}{c}\text { Demand } \\
\text { (Unit) }\end{array}$ \\
\hline $\mathbf{1}$ & 1 - 8 Feb 2018 & 243 \\
$\mathbf{2}$ & 9 - 16 Feb 2018 & 242 \\
$\mathbf{3}$ & 17 - 24 Feb 2018 & 233 \\
$\mathbf{4}$ & 25 Feb - 04 Mar 2018 & 203 \\
$\mathbf{5}$ & 5 - 12 Mar 2018 & 227 \\
$\mathbf{6}$ & 13 - 20 Mar 2018 & 230 \\
$\mathbf{7}$ & 21 - 28 Mar 2018 & 201 \\
\hline
\end{tabular}




\begin{tabular}{clc}
\hline Periode & \multicolumn{1}{c}{ Tanggal } & $\begin{array}{c}\text { Demand } \\
\text { (Unit) }\end{array}$ \\
\hline $\mathbf{8}$ & 29 Mar - 5 Apr 2018 & 281 \\
$\mathbf{9}$ & 6 - 13 Apr 2018 & 255 \\
$\mathbf{1 0}$ & 14 - 21 Apr 2018 & 192 \\
$\mathbf{1 1}$ & 22 - 29 Apr 2018 & 251 \\
\hline
\end{tabular}

Pada Tabel 2 dijelaskan bahwa permintaan produk mengalami fluktuasi. Walaupun permintaan mengalami fluktuasi, terlihat pola permintaan produk membentuk pola kecendrungan peningkatan permintaan walaupun tidak terlalu tinggi. Selain dengan melihat pola pada grafik permintaan, dilakukan peramalan permintaan dengan metode moving average 3 periode, weight moving average 3 periode, exponential smoothing dengan nilai $\alpha=$ 0,1 , trend, naive, dan metode konstan. Setiap metode dibandingkan dengan melihat nilai error pada setiap metode dengan metode ME, MAD, MSE, dan MAPE. Perbandingan nilai error pada setiap metode dijelaskan dalam Tabel 3.

Berdasarkan nilai error, maka metode trend merupakan metode terbaik yang dapat digunakan untuk memprediksi permintaan produk. Hasil peramalan permintaan dengan metode trend dapat dilihat pada Tabel.4. Hasil peramalan pada Tabel 4 dijadikan sebagai input untuk perencanaan kebutuhan material produk.

\subsection{Material Requirement Planning (MRP)}

Sebelum melakukan penyusunan MRP perlu dilakukan identifikasi biaya-biaya inventori untuk bahan baku produk LMHamburger. Komponen biaya pesan untuk produk LM-Hamburger:

1. Biaya pegawai untuk melakukan pemesanan bahan baku dengan gaji UMR kota Tangerang sebesar Rp. 3.500.000

2. Biaya penyusutan rinter dengan umur ekonomis 5 tahun dengan harga $\mathrm{Rp}$. 1.000.000 sebesar Rp. 3.846 per minggu.

3. Biaya telepon, fax dan internet dalam sebulan sebesar Rp. 2.250.000 atau Rp. 562.500 per minggu.

Komponen biaya simpan dari produk

LM-Hamburger adalah sebagai berikut:

1. Biaya pengadaan jasa cleaning service sebesar Rp. 100.000.000 per tahun atau Rp. 1.923.077 per minggu.

2. Biaya pengadaan jasa pembasmi hama sebesar Rp. 150.000.000 per tahun atau Rp. 2884.615 per minggu.
3. Penyusutan palet dengan umur ekonomis 3 tahun sebanyak 2 unit dengan harga Rpp. 100.000 per unit sebesar Rp. 1.282 .000 per minggu.

4. Penyusutan rak dengan umur ekonomis 5 tahun sebanyak 4 unit dengan harga Rp. 3.000.000 per unit sebesar Rp.46.154 per minggu.

5. Penyusutan hand truck dengan umur ekonomis 5 tahun sebanyak 1 unit dengan harga Rp. 2.750 .000 per unit sebesar Rp. 10.577 per minggu.

6. Biaya listrik sebesar Rp. 13.000.000 atau Rp. 3.250.000 per minggu

7. Kapasitas gudang sebesar $5.500 \mathrm{~kg}$.

Setelah melakukan perhitungan biaya pesan dan biaya simpan, dilakukan penyusunan MRP untuk menentukan perencanaan kebutuhan bahan baku produk LM-Hamburger. Berikut adalah langkah-langkah dalam penyusunan MRP produk LM-Hamburger Bun Jempol.

1. Offsetting Produk LM-Hamburger

Berdasarkan hasil perhitugan di atas, nilai persediaan ditangan $(\mathrm{POH})$ dan kebutuhan bersih (NR) memiliki nilai yang sama karena produk pada level 0 merupakan produk jadi hasil produksi dari bahan baku level 1, sehingga tidak ada persediaan bahan baku. Tabel 5 menunjukkan hasil perhitungan offsetting produk.

2. Netting bahan A (level 1)

Pada proses netting diketahui terdapat persediaan awal sebesar $228 \mathrm{~kg}$. Untuk membuat 1 produk LM-Hamburger Bun Jempol dibutuhkan 0,25 $\mathrm{kg}$ bahan A. Tabel 6 merupakan perhitungan netting untuk Bahan A.

3. Netting bahan B (level 1)

Pada proses netting diketahui terdapat persediaan awal bahan B sebesar $66 \mathrm{~kg}$. Untuk membuat 1 produk LM-Hamburger Bun Jempol dibutuhkan 0,025 kg bahan B. Tabel 7 merupakan perhitungan netting untuk Bahan B.

4. Netting bahan C (level 1)

Pada proses netting diketahui terdapat persediaan awal sebesar 12,92 kg. Untuk membuat 1 produk LM-Hamburger Bun Jempol dibutuhkan $0,00325 \mathrm{~kg}$ bahan C. Tabel 8 merupakan perhitungan netting untuk Bahan C. Berdasarkan hasil perhitungan netting, tidak terdapat kebutuhan bersih untuk bahan $\mathrm{C}$ sehingga 
proses lotting dan proses offsetting tidak dilakukan.

Tabel 3. Hasil Error Peramalan Permintaan

\begin{tabular}{clrrrr}
\hline No & \multicolumn{1}{c}{ Metode } & ME & MAD & MSE & MAPE \\
\hline $\mathbf{1}$ & MA 3 & -8.78 & 25.83 & 1103.44 & $11 \%$ \\
$\mathbf{2}$ & WMA 3 & -0.57 & 28.78 & 1298.25 & $13 \%$ \\
$\mathbf{3}$ & Trend & 0.00 & 20.07 & 629.90 & $9 \%$ \\
$\mathbf{4}$ & ES 0.1 & -6.80 & 23.25 & 816.67 & $10 \%$ \\
$\mathbf{5}$ & Naïve & 0.80 & 32.40 & 1693.40 & $14 \%$ \\
$\mathbf{6}$ & Konstan & 2.88 & 20.27 & 639.26 & $9 \%$ \\
\hline
\end{tabular}

Tabel 4. Hasil Peramalan dengan Trend

\begin{tabular}{cc}
\hline Periode & Prediksi (Unit) \\
\hline $\mathbf{1 2}$ & 235 \\
$\mathbf{1 3}$ & 235 \\
$\mathbf{1 4}$ & 236 \\
$\mathbf{1 5}$ & 236 \\
$\mathbf{1 6}$ & 236 \\
$\mathbf{1 7}$ & 237 \\
$\mathbf{1 9}$ & 237 \\
$\mathbf{2 0}$ & 237 \\
$\mathbf{2 1}$ & 238 \\
$\mathbf{2 2}$ & 238 \\
$\mathbf{2 3}$ & 238 \\
\hline
\end{tabular}


Level $0, \mathrm{LT}=0$

Tabel 5. Perhitungan Offsetting Produk LM-Hamburger

\begin{tabular}{|c|c|c|c|c|c|c|c|c|c|c|c|c|}
\hline Periode (Minggu) & 1 & 2 & 3 & 4 & 5 & 6 & 7 & 8 & 9 & $\mathbf{1 0}$ & 11 & 12 \\
\hline Kebutuhan Kotor & 235 & 235 & 236 & 236 & 236 & 237 & 237 & 237 & 238 & 238 & 238 & 239 \\
\hline \multicolumn{13}{|c|}{ Penerimaan Terjadwal (SR) } \\
\hline Persediaan di Tangan & -235 & -235 & -236 & -236 & -236 & -237 & -237 & -237 & -238 & -238 & -238 & -239 \\
\hline Kebutuhan Bersih & 235 & 235 & 236 & 236 & 236 & 237 & 237 & 237 & 238 & 238 & 238 & 239 \\
\hline Rencana penerimaan & 235 & 235 & 236 & 236 & 236 & 237 & 237 & 237 & 238 & 238 & 238 & 239 \\
\hline Rencana Pemesanan & 235 & 235 & 236 & 236 & 236 & 237 & 237 & 237 & 238 & 238 & 238 & 239 \\
\hline
\end{tabular}

Level $1, \mathrm{LT}=1$ minggu

\begin{tabular}{|c|c|c|c|c|c|c|c|c|c|c|c|c|c|}
\hline Periode (Minggu) & $\mathbf{0}$ & 1 & 2 & 3 & 4 & 5 & 6 & 7 & 8 & 9 & 10 & 11 & 12 \\
\hline Kebutuhan Kotor & & 59 & 59 & 59 & 59 & 59 & 59 & 59 & 59 & 60 & 60 & 60 & 60 \\
\hline Penerimaan Terjadwal & & & & & & & & & & & & & \\
\hline Persediaan di Tangan & 228 & 169 & 111 & 52 & -8 & -67 & -126 & -186 & -245 & -304 & -364 & -423 & -483 \\
\hline Kebutuhan Bersih & & & & & 8 & 59 & 59 & 59 & 59 & 60 & 60 & 60 & 60 \\
\hline
\end{tabular}

Tabel 7. Perhitungan Netting Bahan B (0.025kg)

Level $1, \mathrm{LT}=0$

\begin{tabular}{|c|c|c|c|c|c|c|c|c|c|c|c|c|c|}
\hline Periode (Minggu) & $\mathbf{0}$ & 1 & 2 & 3 & 4 & 5 & 6 & 7 & 8 & 9 & 10 & 11 & 12 \\
\hline Kebutuhan Kotor & & 5.8 & 5.8 & 5.9 & 5.9 & 5.9 & 5.93 & 5.93 & 5.93 & 5.95 & 5.95 & 5.95 & 5.98 \\
\hline $\begin{array}{l}\text { Penerimaan Terjadwal } \\
\text { Persediaan di Tangan }\end{array}$ & 66 & 60 & 54 & 48 & 42 & 37 & 31 & 25 & 19 & 13 & 7 & 0.93 & -5.05 \\
\hline Kebutuhan Bersih & & & & & & & & & & & & & 5.05 \\
\hline
\end{tabular}

Tabel 8. Perhitungan Netting Bahan C (0.00325)

Level 1 , LT = 1 minggu

Periode (Minggu)

Kebutuhan Kotor

Penerimaan Terjadwal (SR)

Persediaan di Tangan 0

\begin{tabular}{rrrrrrrrrrrr}
$\mathbf{1}$ & $\mathbf{2}$ & $\mathbf{3}$ & $\mathbf{4}$ & $\mathbf{5}$ & $\mathbf{6}$ & $\mathbf{7}$ & $\mathbf{8}$ & $\mathbf{9}$ & $\mathbf{1 0}$ & $\mathbf{1 1}$ & $\mathbf{1 2}$ \\
\hline 0.7 & 0.7 & 0.7 & 0.7 & 0.7 & 0.7 & 0.7 & 0.7 & 0.7 & 0.7 & 0.7 & 0.7 \\
12.1 & 11.3 & 10.6 & 9.8 & 9 & 8.3 & 7.5 & 6.7 & 6 & 5.2 & 4.4 & 3.6 \\
- & - & - & - & - & - & - & - & - & - & - & - \\
\hline
\end{tabular}


Level 1, LT = 1 minggu

\begin{tabular}{|c|c|c|c|c|c|c|c|c|c|c|c|c|c|c|}
\hline Periode (Minggu) & -1 & $\mathbf{0}$ & 1 & 2 & 3 & 4 & 5 & 6 & 7 & 8 & 9 & 10 & 11 & 12 \\
\hline Kebutuhan Kotor & & & 0.71 & 0.71 & 0.71 & 0.71 & 0.71 & 0.71 & 0.71 & 0.71 & 0.71 & 0.71 & 0.71 & 0.72 \\
\hline Penerimaan Terjadwal & & & & & & & & & & & & & & \\
\hline Persediaan di Tangan & & 19 & 18.3 & 17.6 & 16.9 & 16.2 & 15.5 & 14.8 & 14.0 & 13.3 & 12.6 & 11.9 & 11.2 & 10.5 \\
\hline Kebutuhan Bersih & & & - & - & - & & - & - & - & - & - & - & - & - \\
\hline
\end{tabular}

Tabel 9. Perhitungan Netting Bahan D (0.003 kg)

Tabel 10. Perhitungan Netting Bahan E (0.00125)

Level 1, LT $=0$

\begin{tabular}{|c|c|c|c|c|c|c|c|c|c|c|c|c|c|c|}
\hline Periode (Minggu) & -1 & $\mathbf{0}$ & 1 & 2 & 3 & 4 & 5 & 6 & 7 & 8 & 9 & 10 & 11 & 12 \\
\hline Kebutuhan Kotor & & & 0.2 & 0.2 & 0.2 & 0.2 & 0.2 & 0.2 & 0.2 & 0.2 & 0.2 & 0.2 & 0.2 & 0.2 \\
\hline Penerimaan Terjadwal & & & & & & & & & & & & & & \\
\hline Persediaan di Tangan & & 16.7 & 16.4 & 16.1 & 15.8 & 15.5 & 15.2 & 14.9 & 14.6 & 14.3 & 14 & 13.7 & 13.4 & 13.1 \\
\hline Kebutuhan Bersih & & & - & & - & - & - & - & - & - & - & - & - & - \\
\hline
\end{tabular}

Tabel 11. Perhitungan Netting Bahan F (0.0125)

Level 1, LT $=0$

\begin{tabular}{|c|c|c|c|c|c|c|c|c|c|c|c|c|c|c|}
\hline Periode (Minggu) & -1 & $\mathbf{0}$ & 1 & 2 & 3 & 4 & 5 & 6 & 7 & 8 & 9 & 10 & 11 & 12 \\
\hline Kebutuhan Kotor & & & 2.94 & 2.94 & 2.95 & 2.9 & 2.95 & 2.96 & 2.96 & 2.9 & 2.9 & 2.9 & 2.9 & 2.9 \\
\hline Penerimaan Terjadwal & & & & & & & & & & & & & & \\
\hline $\begin{array}{l}\text { Persediaan di Tangan } \\
\text { Kebutuhan Bersih }\end{array}$ & & 31.1 & 28.2 & 25.2 & 22.3 & 19.3 & 16.4 & 13.4 & 10.5 & 7.5 & 4.5 & 1.6 & $\begin{array}{r}-1.3 \\
1.3\end{array}$ & $\begin{array}{r}-4.3 \\
2.9\end{array}$ \\
\hline
\end{tabular}

Level $1, \mathrm{LT}=1$ minggu

Tabel 12. Perhitungan Netting Bahan G (0.025 kg)

\begin{tabular}{|c|c|c|c|c|c|c|c|c|c|c|c|c|c|c|}
\hline Periode (Minggu) & -1 & $\mathbf{0}$ & 1 & 2 & 3 & 4 & 5 & 6 & 7 & 8 & 9 & 10 & 11 & 12 \\
\hline Kebutuhan Kotor & & & 5.8 & 5.8 & 5.9 & 5.9 & 5.9 & 5.9 & 5.9 & 5.9 & 5.9 & 5.9 & 5.9 & 5.9 \\
\hline Penerimaan Terjadwal & & & & & & & & & & & & & & \\
\hline Persediaan di Tangan & & 30 & 24.1 & 18.3 & 12.4 & 6.5 & 0.5 & -5.4 & -11.3 & -17.2 & -23.2 & -29.1 & -35.1 & -41.1 \\
\hline Kebutuhan Bersih & & & & & & & & 5.3 & 5.9 & 5.93 & 5.9 & 5.95 & 5.9 & 5.98 \\
\hline
\end{tabular}


Tabel 13. Perhitungan Netting Bahan $\mathrm{H}(0.1 \mathrm{~kg})$

Level $1, \mathrm{LT}=0$

Periode (Minggu)

Kebutuhan Kotor (GR)

Tabel 13. Perhitungan Netting Bahan H $(0.1 \mathrm{~kg})$

Penerimaan Terjadwal (SR)

$-1 \quad 0$

1

$\begin{array}{lll}\mathbf{1} & \mathbf{2} & \mathbf{3} \\ 23.5 & 23.5 & 23.6\end{array}$

4

6

Persediaan di Tangan

Kebutuhan Bersih (NR)

$23.5 \quad 23.5 \quad 23.6$

Rencana Penerimaan (PO Rec)

$23.5 \quad 23.5$

23.6
23.6

23.6

$23.6-23.7$

7

8

3.7

9

Rencana Pemesanan (PO Rel)

$\begin{array}{llllll}23.5 & 23.5 & 23.6 & 23.6 & 23.6 & 23.7 \\ 23.5 & 23.5 & 23.6 & 23.6 & 23.6 & 23.7\end{array}$


5. Netting bahan D (level 1)

Pada proses netting diketahui terdapat persediaan awal bahan D sebesar $19 \mathrm{~kg}$. Untuk membuat 1 produk LM-Hamburger dibutuhkan $0,003 \mathrm{~kg}$ bahan D. Tabel 9 merupakan perhitungan netting untuk Bahan D. Berdasarkan hasil perhitungan netting, tidak terdapat kebutuhan bersih untuk bahan D sehingga proses lotting dan proses offsetting tidak dilakukan.

6. Netting bahan E (level 1)

Pada proses netting diketahui terdapat persediaan awal bahan E sebesar $16,72 \mathrm{~kg}$. Untuk membuat 1 produk LM-Hamburger Bun Jempol dibutuhkan $0,00125 \mathrm{~kg}$ bahan E. Tabel 10 merupakan perhitungan netting untuk Bahan E.

7. Netting bahan F (Level 1)

Pada proses netting diketahui terdapat persediaan awal bahan $\mathrm{F}$ sebesar $31,16 \mathrm{~kg}$. Untuk membuat 1 produk LM-Hamburger Bun Jempol dibutuhkan 0,0125 kg bahan F. Tabel 11 merupakan perhitungan netting untuk Bahan F. Berdasarkan hasil perhitungan netting, persediaan awal mampu memenuhi kebutuhan bahan baku sampai periode ke-10, sehingga kebutuhan bahan baku hanya terdapat pada periode ke-11 dan 12.

8. Netting bahan $\mathrm{G}$ (level 1)

Pada proses netting diketahui terdapat persediaan awal sebesar $30 \mathrm{~kg}$. Untuk membuat 1 produk LM-Hamburger Bun Jempol dibutuhkan $0,025 \mathrm{~kg}$ bahan G. Tabel 12 merupakan perhitungan netting untuk Bahan G.

\section{Netting bahan $\mathrm{H}$ (level 1)}

Bahan $\mathrm{H}$ merupakan bahan yang bisa langsung digunakan tanpa perlu dipesan dan tidak bisa disimpan. Maka proses MRP untuk bahan $\mathrm{H}$ hanya dilakukan sampai dengan proses netting tanpa lotting dan offsetting. Tabel 13 adalah lotting bahan $\mathrm{H}$.

Setelah melakukan perhitungan Netting, dilakukan perhitungan lotting dan offsetting untuk menentukan metode terbaik. Metode terbaik didasarkan pada total biaya inventori terendah. Setelah dilakukan perhitungan total biaya inventori, terdapat rekapitulasi biaya inventori dengan metode Silver-Meal, LTC, dan LUC. Berikut merupakan perhitungan total biaya inventori dengan metode Silver-Meal.

Berdasarkan hasil perhitungan biaya inventori seperti terlihat pada Tabel 14, biaya inventori terbesar adalah bahan A sebesar Rp. 5.573.440 dan biaya inventori terendah adalah bahan C sebesar Rp. 609.950 dengan total biaya inventori sebesar Rp. 17.289.584. Biaya inventori dengan metode Silver-Meal lebih rendah dibanding metode LUC karena cakupan periode simpan pada bahan A dengan metode Silver-Meal lebih sedikit dibanding dengan metode LUC. Sementara itu, total biaya simpan dengan metode Silver-Meal lebih tinggi dibanding metode LTC. Walaupun biaya simpan pada metode LTC lebih rendah dibanding metode Silver-Meal, biaya pesan dengan menggunakan metode Silver-Meal lebih rendah dibanding dengan metode LTC karena frekuensi pemesanan dengan metode Silver-Meal sedikit daripada metode LTC. Hal tersebut membuktikan bahwa biaya pesan bukan merupakan faktor utama dalam menentukan tinggi atau rendahnya biaya inventori suatu metode.

Tabel 14. Rekapitulasi Biaya Inventori dengan Metode Silver-Meal

\begin{tabular}{ccrrr}
\hline No & Bahan & Biaya Pesan (Rp) & Biaya Simpan (Rp) & Total Biaya (Rp) \\
\hline $\mathbf{1}$ & $\mathrm{A}$ & 2.882 .692 & 2.690 .748 & 5.573 .440 \\
$\mathbf{2}$ & $\mathrm{B}$ & 1.441 .346 & 1.521 .719 & 2.963 .065 \\
$\mathbf{3}$ & $\mathrm{C}$ & 0 & 609.950 & 609.950 \\
$\mathbf{4}$ & $\mathrm{D}$ & 0 & 1.252 .137 & 1.252 .137 \\
$\mathbf{5}$ & $\mathrm{E}$ & 0 & 1.379 .309 & 1.379 .309 \\
$\mathbf{6}$ & $\mathrm{F}$ & 1.441 .346 & 2.103 .616 & 3.544 .962 \\
$\mathbf{7}$ & $\mathrm{G}$ & 1.441 .346 & 525.375 & 1.966 .721 \\
$\mathbf{8}$ & $\mathrm{H}$ & 0 & 0 & 0 \\
\hline \multicolumn{7}{r}{} \\
\hline
\end{tabular}


Tabel 15. Rekapitulasi Biaya Inventori dengan Metode LTC

\begin{tabular}{rrrrr}
\hline No & Bahan & Biaya Pesan (Rp) & Biaya Simpan (Rp) & Total Biaya (Rp) \\
\hline $\mathbf{1}$ & $\mathrm{A}$ & 4.324 .038 & 1.168 .992 & 5.493 .030 \\
$\mathbf{2}$ & $\mathrm{B}$ & 1.441 .346 & 1.521 .719 & 2.963 .065 \\
$\mathbf{3}$ & $\mathrm{C}$ & 0 & 609.950 & 609.950 \\
$\mathbf{4}$ & $\mathrm{D}$ & 0 & 1.252 .137 & 1.252 .137 \\
$\mathbf{5}$ & $\mathrm{E}$ & 0 & 1.379 .309 & 1.379 .309 \\
$\mathbf{6}$ & $\mathrm{F}$ & 1.441 .346 & 2.103 .616 & 3.544 .962 \\
$\mathbf{7}$ & $\mathrm{G}$ & 1.441 .346 & 537.020 & 1.978 .366 \\
$\mathbf{8}$ & $\mathrm{H}$ & 0 & 0 & 0 \\
\hline \multicolumn{7}{r}{} \\
\hline
\end{tabular}

Tabel 16. Rekapitulasi Biaya Inventori dengan Metode LUC

\begin{tabular}{ccrrr}
\hline No & Bahan & Biaya Pesan (Rp) & Biaya Simpan (Rp) & Total Biaya (Rp) \\
\hline $\mathbf{1}$ & $\mathrm{A}$ & 2.882 .692 & 3.775 .977 & 6.658 .669 \\
$\mathbf{2}$ & $\mathrm{B}$ & 1.441 .346 & 1.521 .719 & 2.963 .065 \\
$\mathbf{3}$ & $\mathrm{C}$ & 0 & 609.950 & 609.950 \\
$\mathbf{4}$ & $\mathrm{D}$ & 0 & 1.252 .137 & 1.252 .137 \\
$\mathbf{5}$ & $\mathrm{E}$ & 0 & 1.379 .309 & 1.379 .309 \\
$\mathbf{6}$ & $\mathrm{F}$ & 1.441 .346 & 2.103 .616 & 3.544 .962 \\
$\mathbf{7}$ & $\mathrm{G}$ & 1.441 .346 & 537.020 & 1.978 .366 \\
$\mathbf{8}$ & $\mathrm{H}$ & 0 & 0 & 0 \\
\hline \multicolumn{7}{r}{} \\
\hline
\end{tabular}

Berdasarkan hasil perhitungan biaya inventori seperti ditunjukkan pada Tabel 15, biaya inventori terbesar adalah bahan A sebesar Rp. 5.493.030 dan biaya inventori terendah adalah bahan C sebesar Rp. 609.950 dengan total biaya inventori sebesar Rp. 17.220.819. Total biaya inventori dengan metode LTC merupakan yang paling rendah dibanding metode Silver-Meal dan LTC karena pada bahan A cakupan periode simpan pada metode LTC merupakan yang paling kecil. Cakupan periode yang lebih sedikit menghasilkan ongkos simpan yang lebih kecil dibanding metode Silver-Meal dan LTC, namun biaya pesan dengan menggunakan metode LTC merupakan yang paling besar dibanding metode Silver-Meal dan LUC.

Perhitungan biaya pesan menggunakan metode LTC menghasilkan biaya yang paling tinggi dibanding metode Silver-Meal dan LUC karena memiliki frekuensi pemesanan yang paling tinggi. Dengan mengurangi waktu simpan, total biaya inventori dapat dikurangi walaupun menghasilkan biaya pesan yang lebih tinggi. Walaupun biaya pesan bukan merupakan faktor utama dalam menentukan tinggi rendahnya total biaya inventori pada suatu metode, frekuensi pemesanan yang terlalu banyak dapat mengakibatkan tingginya biaya inventori. Oleh karena itu, cara yang dapat dilakukan untuk memperkecil biaya inventori adalah dengan menyeimbangkan antara frekuensi pemesanan dengan periode simpan.

Tabel 16 merupakan perhitungan total biaya inventori dengan metode LUC. Berdasarkan hasil perhitungan biaya inventori, biaya inventori terbesar adalah bahan A sebesar Rp. 6.658.669 dan biaya inventori terendah adalah bahan $\mathrm{C}$ sebesar Rp. 609.950 dengan total biaya inventori sebesar Rp. 18.386.458. Teknik LUC menghasilkan total biaya inventori terbesar dibanding metode lain karena pada Bahan A terdapat cakupan periode simpan terbesar yaitu selama 6 periode. Cakupan periode simpan yang terlalu lama menyebabkan meningkatnya ongkos simpan karena satuan ongkos simpan adalah kilogram/periode. Sedangkan biaya simpan dengan teknik LUC sama dengan teknik Silver-Meal. Namun total biaya inventori meningkat karena periode simpan yang terlalu lama. Ketika frekuensi pemesanan bahan baku memiliki jumlah yang sama, maka periode simpan akan mempengaruhi tinggi atau rendahnya total biaya inventori.

Berdasarkan hasil perhitungan ukuran lot ekonomis dengan metode Silver-Meal, LTC, dan LUC ukuran lot ekonomis untuk bahan A terdapat metode LTC karena metode tersebut memiliki ongkos inventori terkecil dibanding metode Silver-Meal dan LTC. Dengan menggunakan metode LTC, perusahaan harus melakukan pemesanan ulang bahan A sebanyak 
200 kilogram pada periode ke-3, 225 kilogram pada periode ke-7, dan 75 kilogram pada periode ke-11.

Perhitungan lotting untuk bahan B tidak dilakukan karena kebutuhan material hanya terdapat pada periode ke-12. Perhitungan lotting, dan offsetting bahan C, D, dan E tidak perlu dilakukan pemesanan ulang karena tidak terdapat kebutuhan material. Sementara itu, untuk bahan $\mathrm{F}$ dan bahan $\mathrm{G}$ perhitungan lotting dengan metode Silver Meal, LTC, dan LUC memiliki nilai yang sama sehingga nilai offsetting untuk bahan $\mathrm{F}$ dan $\mathrm{G}$ memiliki nilai yang sama.

Dari segi biaya, bahan A memiliki biaya inventori tertinggi karena kebutuhan material bahan A pada struktur produk merupakan yang paling banyak dibandingkan dengan bahan baku lain. Selain itu, persediaan awal bahan A merupakan yang tertinggi dibandingkan dengan bahan baku lain yang menyebabkan biaya simpan meningkat.

\section{SIMPULAN}

Ukuran lot optimal untuk bahan A sebesar 200 kilogram untuk mencakup 4 periode, 225 kilogram untuk mencakup 4 periode, dan 75 kilogram untuk mencakup 1 periode. Bahan A memiliki ukuran lot optimal sebesar 50 kilogram untuk mencakup 1 periode. Bahan C, D, dan E tidak perlu dilakukan pemesanan karena tidak terdapat kebutuhan material. Ukuran lot optimal bahan F sebesar 25 kilogram untuk mencakup 2 periode, dan ukuran lot bahan $\mathrm{G}$ sebesar 45 kilogram untuk mencakup 7 periode.

Bahan A dapat dipesan ulang pada periode ke-3 sebesar 200 kilogram, periode ke-7 sebesar 225 kilogram, dan periode ke-11 sebesar 75 kilogram. Bahan B dapat dipesan kembali pada periode ke-12 sebesar 50 kilogram. Bahan F dapat dipesan kembali pada periode ke-11 sebesar 25 kilogram, dan bahan $\mathrm{G}$ dapat dipesan pada periode ke-5 sebesar 45 kilogram.

Berdasarkan hasil perhitungan biaya, total biaya inventori dengan metode LTC sebesar Rp. 17.220.819 dengan komposisi biaya inventori bahan A sebesar Rp. 5.493.030, bahan B sebesar
Rp. 2.963.065, bahan C sebesar Rp. 609.950, bahan D sebesar Rp. 1.252.137. Total biaya inventori bahan E sebesar Rp. 1.379.309, bahan F sebesar Rp. 3.544.962, dan bahan G sebesar Rp. 1.978.366.

\section{DAFTAR PUSTAKA}

Bahagia, S. N. (2006) Sistem Inventori. Bandung: Penerbit ITB.

Fachrurrozi dan Almahdy, I. (2016) "Lot Sizing Material Requirement Planning pada Produk Tipe Wall Mounting di Industri Box Panel," Penelitian dan Aplikasi Sistem dan Teknik Industri, 10(3), hal. 279-293. Tersedia pada: https://media.neliti.com/media/publicatio ns/182840-ID-lot-sizing-materialrequirement-planning.pdf.

Gaspersz, V. (2012) Production and Inventory Management for Supply Chain Professionals. Bogor: Vinchristo Publication.

Ginting, R. (2007) Sistem Produksi. Yogyakarta: Graha Ilmu.

Herjanto, E. (2001) Manajemen Produksi dan Operasi. 2 ed. Jakarta: Grasindo.

Kusuma, H. (2009) Perencanaan dan Pengendalian Produksi. Yogyakarta: Andi.

Madinah, W. N., Sumantri, Y. dan Azlia, W. (2015) "Penentuan Metode Lot Sizing pada Perencanaan Pengadaan Bahan Baku Kikir dan Mata Bor," Jurnal Rekayasa dan Manajemen Sistem Industri, 3(3), hal. 505-515.

Rangkuti, F. (2007) Manajemen Persediaan: Aplikasi di Bidang Bisnis. Jakarta: Rajagrafindo Persada.

Russell R. S. dan Taylor B. W. (2011) Operations Management: Creating Value along the Supply Chain. 7 ed. Hoboken: John Wiley \& Sons.

Tersine, R. J. (1994) Principles of Inventory and Materials Management. 4 ed. New Jersey: Prentice Hall. 